\title{
The Isolation and Characterization of Agarolytic Bacteria from a Lowland River
}

\author{
By JOHN A. C. AGBO* AND MAURICE O. MOSS \\ Department of Microbiology, University of Surrey, \\ Guildford, Surrey GU2 $5 X H$
}

(Received 27 February 1979; revised 17 May 1979)

Several strains of agar-degrading bacteria were isolated from the River Wey, Guildford, during the summer of 1976. All were Gram-negative rods and could be divided into two groups. Those which only softened the agar belonged to the genus Cytophaga and those which caused extensive liquefaction of the agar have been referred to the genus Alteromonas. Attempts to isolate, purify and characterize the enzymes showed some differences between the two taxa. The strains of Cytophaga produced at least two enzyme complexes, one cell-free and the other cell-bound, and hydrolysed agar with the formation of oligosaccharides. The strains of Alteromonas, on the other hand, readily released 'agarase' into the medium yielding monosaccharides as major end-products. The agar-degrading enzymes of both groups were inducible, not only by agar, but also by other galactans and polysaccharides associated with plants. The enzyme preparations also hydrolysed a wide range of plant-derived polysaccharides, including some associated with terrestrial and freshwater plants rather than with marine algae. These results suggest that there is no special ecological reason for the presence of agarolytic bacteria in fresh water but that their activity reflects the wide substrate spectrum of the polysaccharides of such organisms. The agar-softening strains are considered to belong to a new species for which the name Cytophaga saccharophila is proposed.

\section{INTRODUCTION}

Agar is a complex polysaccharide produced by marine red algae from genera such as Gelidium, Gracilaria and Ceramium. It contains a neutral agarose fraction and an ionic agaropectin fraction (Araki, 1937) but both fractions are thought to consist of alternating units of $(1 \rightarrow 3)-\beta$-D-galactopyranoside and $(1 \rightarrow 4)-3,6$-anhydro- $\alpha$-L-galactoside. In the ionic agaropectin fraction the galactoside units may be methylated or contain pyruvic or sulphuric acid residues (Araki, 1956; Duckworth \& Yaphe, 1971 $a, b$; Izumi, 1972).

The firm gel formed when a 1.5 to $2.0 \%(\mathrm{w} / \mathrm{v})$ solution of agar in boiling water is allowed to cool is believed to be a matrix of double helical polymers held together by hydrogen bonds (Ng Ying Kin \& Yaphe, 1972). The gel may be degraded by micro-organisms in three ways. (1) Disruption of the double helical structure without breakdown of the polymer. This does not generally produce any visible changes in the gel and such limited activity can only be detected by the failure to form the brown colour that the normal gel forms with iodine (Gran, 1902). This colour is thought to depend on the integrity of the double helical structure ( $\mathrm{Ng}$ Ying Kin \& Yaphe, 1972). (2) Cleavage of the $\alpha$-linkages of the agar molecule, giving rise to oligosaccharides of the agarobiose series with 3,6-anhydroL-galactose at the reducing end. (3) Cleavage of the $\beta$-linkages, giving rise to the neo-

* Present address: Department of Microbiology, University of Nigeria, Nsukka, E. Nigeria. 
agarobiose series of oligosaccharides with D-galactose at the reducing end. The enzymes involved in (2) and (3) are called $\alpha$ - and $\beta$-agarases, respectively; most agarolytic bacteria so far described are considered to produce only $\beta$-agarase (Yaphe, 1966; Turvey \& Christison, 1967; Vattuone et al., 1975; van der Meulen \& Harder, 1975). Visible changes caused by cleavage of the agar molecule range from softening of the surface of the gel to the formation of craters and eventual complete liquefaction.

Although many isolates associated with agarolytic activity have been named in the literature, the 8th edition of Bergey's Manual (Buchanan \& Gibbons, 1974) retains very few fully described species. The Gram-negative species occur in the genera Cytophaga and Flavobacterium while many isolates previously placed in the genera Vibrio and Pseudomonas are no longer accepted as belonging to those genera. Most agarolytic bacteria have been isolated from marine habitats but recent isolations from other sources have been reported by v. Hofsten \& Malmqvist (1975), van der Meulen et al. (1974) and Hunger \& Claus (1978).

During a study of the bacteria which contribute to the degradation of the macromolecular organic materials of plant origin in the River Wey, a number of agar-degrading organisms were isolated. The present study was undertaken in an attempt to characterize these agarolytic isolates and to understand their role in a freshwater habitat.

\section{METHODS}

Sampling. Water samples were collected from the River Wey at Guildford over a 9 month period. During any one session, seven samples were collected simultaneously in sterile $500 \mathrm{ml}$ bottles from a range of depths in the river using the device illustrated in Fig. 1. Viable bacteria were estimated by spreading $0.1 \mathrm{ml}$ of dilutions of each sample on plates of quarter-strength nutrient broth solidified with $1.5 \%(\mathrm{w} / \mathrm{v})$ Davis agar (0.25NA) and counting colonies after $7 \mathrm{~d}$ incubation at $25^{\circ} \mathrm{C}$.

Enrichment and isolation of agarolytic bacteria. Erlenmeyer flasks $(250 \mathrm{ml})$ containing sterile river water $(100 \mathrm{ml})$, to which $0.1 \%(\mathrm{w} / \mathrm{v})$ Oxoid no. 3 agar had been added, were inoculated with river water samples $(20 \mathrm{ml})$ and incubated at $25^{\circ} \mathrm{C}$ on a rotary shaker for $4 \mathrm{~d}$. Samples $(0.1 \mathrm{ml})$ of the cultures were then plated on a mineral medium containing ( $\mathrm{g} \mathrm{l}^{-1}$ in deionized water): $\mathrm{KH}_{2} \mathrm{PO}_{4}(1 \cdot 0) ; \mathrm{NH}_{4} \mathrm{Cl}(0.5) ; \mathrm{MgSO}_{4} .7 \mathrm{H}_{2} \mathrm{O}$ $(0 \cdot 5) ; \mathrm{CaCl}_{2} .2 \mathrm{H}_{2} \mathrm{O}(0 \cdot 1)$; Oxoid no. 3 agar (15); adjusted to $\mathrm{pH} 7 \cdot 2$ before autoclaving at $121{ }^{\circ} \mathrm{C}$ for $15 \mathrm{~min}$. Plates were incubated at $25^{\circ} \mathrm{C}$ and examined daily for agarolytic activity, assessed by liquefaction or shallow depressions appearing around the colonies. After $7 \mathrm{~d}$, plates were flooded with Lugol's iodine and the appearance of pale-yellow zones around colonies against a reddish-violet background was considered indicative of some agar-degrading activity in the absence of the visible signs already referred to. All colonies showing liquefaction or depressions in the agar were picked off and purified by streaking out on mineral or nutrient agar.

Representative agar-degrading strains were maintained in Dubos' solution containing $\left(\mathrm{g} \mathrm{l}^{-1}\right): \mathrm{NaNO}_{3}$ $(0 \cdot 5) ; \mathrm{K}_{2} \mathrm{HPO}_{4}(0 \cdot 1) ; \mathrm{MgSO}_{4} .7 \mathrm{H}_{2} \mathrm{O}(0.5) ; \mathrm{FeSO}_{4} .7 \mathrm{H}_{2} \mathrm{O}(0 \cdot 01)$; adjusted to $\mathrm{pH} 7 \cdot 2$, dispensed into Bijou bottles and sterilized at $121{ }^{\circ} \mathrm{C}$ for $15 \mathrm{~min}$.

Strains used for detailed examination. Eleven strains representing the non-pigmented, motile, agarliquefying isolates and six representing the pigmented, agar-softening isolates were examined along with agarolytic strains NCIB 9491 (Mitchell et al., 1969) and NCMB 1914 (v. Hofsten \& Malmqvist, 1975), obtained from the National Collections of Industrial and Marine Bacteria, Torry Research Station, Aberdeen. Pseudomonas putrefaciens (NCIB 10472) and P. rubescens (NCIB 8768), obtained from the culture collection of the Department of Microbiology, University of Surrey, were included as non-agarolytic reference strains. Pseudomonas putrefaciens and P. rubescens are considered to be synonyms of Alteromonas putrefaciens (Lee et al., 1977).

All tests were carried out at $25^{\circ} \mathrm{C}$ unless stated otherwise.

Colonial and cell morphology. Colonial characteristics and pigmentation were studied on plates of nutrient agar, with and without $30 \%$ (v/v) skim milk (Shewan et al., 1960), on river water agar, mineral medium agar and the media of King et al. (1954).

Motility (hanging drop), Gram-staining (modification of Preston \& Morrel) and examination for microcyst formation in yellow-pigmented isolates (Stanier, 1942) were done on bacteria grown in peptone $(1.5 \%, w / v)$ water for $48 \mathrm{~h}$. Cell morphology and flagellation were studied using a Jeol transmission electron microscope (JEM 100B). Bacteria grown on nutrient agar plates for 24 to $96 \mathrm{~h}$ were harvested 


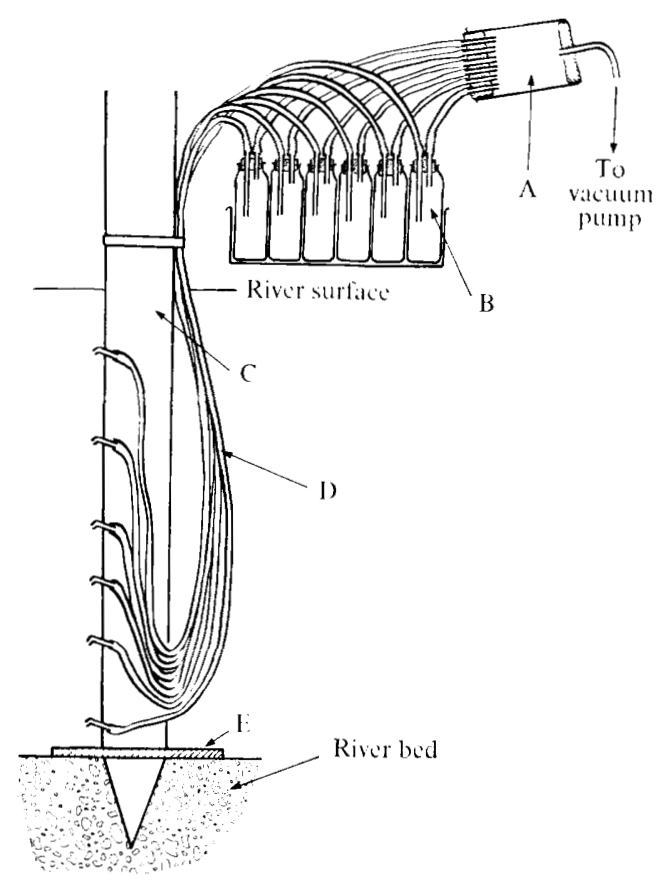

Fig. 1. River sampling apparatus: A, vacuum reservoir; B, rack of $500 \mathrm{ml}$ sampling bottles; C, hollow rigid plastic column to support sampling tubes; $D$, sterilizable plastic tubing (the lengths were adjusted to provide an equivalent sampling rate from each depth; the dead space of the tubing was considered to be negligible compared with the sample size); E, metal base plate.

in sterile distilled water, centrifuged at $40 \mathrm{~g}$ for $30 \mathrm{~min}$, washed once with $10 \%(\mathrm{v} / \mathrm{v})$ aqueous dimethyl sulphoxide to remove extracellular polysaccharide and twice in distilled water. The washed bacteria were suspended in 1 vol. $0.025 \%(\mathrm{w} / \mathrm{v})$ bovine serum albumin and mixed with 2 vol. $2 \%(\mathrm{w} / \mathrm{v})$ aqueous phosphotungstic acid previously adjusted to $\mathrm{pH} \mathrm{7.2} \mathrm{with} 1 \mathrm{M}-\mathrm{KOH}$. After standing for 30 to $60 \mathrm{~min}$, drops of the stained suspension were pipetted on to Formvar-coated copper grids, dried and examined in the electron microscope at an accelerating voltage of $80 \mathrm{kV}$.

Physiological tests. Growth at temperatures between 4 and $50^{\circ} \mathrm{C}$ was tested on slopes of $0 \cdot 25 \mathrm{NA}$, or in tubes of $0.25 \mathrm{NB}$, incubated in an aluminium temperature gradient block. Growth on slopes was assessed visually and that in broth spectrophotometrically at $546 \mathrm{~nm}$ (Unicam SP600).

Growth at $\mathrm{pH}$ values between 4 and 9 was tested in mineral medium containing $0.2 \%(\mathrm{w} / \mathrm{v})$ agar, adjusted with either $0.2 \mathrm{M}-\mathrm{K}_{2} \mathrm{HPO}_{4}$ or $0.2 \mathrm{M}-\mathrm{KH}_{2} \mathrm{PO}_{4}$.

Sodium chloride tolerance was tested on plates of a medium containing $\left(\mathrm{g} \mathrm{l}^{-1}\right)$ : peptone (Oxoid), 1.25 ; yeast extract (Oxoid), 0.5; agar (Oxoid no. 3), 15; and $\mathrm{NaCl}$ up to 10\% (w/v). Growth was assessed after $5 \mathrm{~d}$.

The ability to grow anaerobically was tested by incubating plates of nutrient agar in anaerobic jars with an atmosphere of hydrogen for $5 \mathrm{~d}$.

Biochemical tests. Strains were tested for catalase, indole (Kovacs' method), $\mathrm{H}_{2} \mathrm{~S}$ (method 3) and phosphatase (method 1) production, methyl red and Voges-Proskauer (Barritt's method) reactions, nitrate reduction (method 1) and gelatin hydrolysis (method 1 at $20^{\circ} \mathrm{C}$ for $7 \mathrm{~d}$ ) (all according to Cowan \& Steel, 1974), oxidase activity (Kovacs, 1956), DNAase activity (Jeffries et al., 1957) using Bacto DNAase test agar (Difco), arginine dihydrolase production (Thornley, 1960) and decarboxylation of arginine, ornithine and lysine (Møller, 1955). Tests were examined after 5 and $10 \mathrm{~d}$ except where otherwise indicated.

The $\mathrm{O} / \mathrm{F}$ test (Cowan \& Steel, 1974) was done using the basal medium of Hugh \& Leifson (1953) containing $1 \%(\mathrm{w} / \mathrm{v})$ glucose. The agar-liquefying strains were further examined on plates of the same medium, incubating one set aerobically and the other set in an anaerobic jar with hydrogen. Both tubes and plates were examined after 7 and $14 \mathrm{~d}$.

Starch hydrolysis was examined by incubating plates of yeast extract agar (Difco) containing $0 \cdot 2 \%(\mathrm{w} / \mathrm{v})$ soluble starch (Fisons) for $4 \mathrm{~d}$ and then flooding with Lugol's iodine. Alternatively, where liquefaction of the agar was a nuisance, tubes of peptone water containing $0.1 \%(\mathrm{w} / \mathrm{v}) \mathrm{K}_{2} \mathrm{HPO}_{4}$ and $1.0 \%$ (w/v) soluble starch were used. After $14 \mathrm{~d}$, residual starch was tested for by adding a drop of Lugol's iodine. Cellulose 
Table 1. Characters used for numerical taxonomy and other compounds tested as sole carbon source

\begin{tabular}{|c|c|c|}
\hline \multicolumn{3}{|c|}{ Numerical taxonomy } \\
\hline Non-diffusible & & tilization of: \\
\hline Diffusible pigm & & Glycine \\
\hline Rapid motility & & Isoleucine \\
\hline Gliding motility & & Threonine \\
\hline Polar flagella & & Aspartate \\
\hline Hugh \& Leifsor & & Arginine \\
\hline $\mathrm{O}$ (acid) & & Proline \\
\hline $\mathrm{O}$ (alkaline) & & Malate \\
\hline $\mathrm{F}$ & & Glycerol \\
\hline No growth & & Glucose \\
\hline Growth at: & & Ribose \\
\hline $37^{\circ} \mathrm{C}$ & & Xylose \\
\hline $41^{\circ} \mathrm{C}$ & & Arabinose \\
\hline Growth with: & & Galactose \\
\hline $0 \%(\mathrm{w} / \mathrm{v}) \mathrm{Na}$ & & $N$-Acetylglucosamine \\
\hline $2 \%(\mathrm{w} / \mathrm{v}) \mathrm{Na}$ & & Glucosamine \\
\hline $3 \%(\mathrm{w} / \mathrm{v}) \mathrm{Na}$ & & Trehalose \\
\hline $7 \%(\mathrm{w} / \mathrm{v}) \mathrm{Na}$ & & Raffinose \\
\hline $10 \%(\mathrm{w} / \mathrm{v}) \mathrm{N}$ & & Benzoate \\
\hline Indole producti & & p-Hydroxybenzoate \\
\hline Voges-Proskaue & & $m$-Hydroxybenzoate \\
\hline Methyl red & & ensitivity to: \\
\hline DNAase & & Tetracycline $(10 \mu \mathrm{g})$ \\
\hline Phosphatase & & Erythromycin $(15 \mu \mathrm{g})$ \\
\hline Amylase & & Chloramphenicol $(10 \mu \mathrm{g})$ \\
\hline Liquefaction of & & Polymyxin (300 units) \\
\hline Liquefaction of & & Streptomycin $(10 \mu \mathrm{g})$ \\
\hline Softening of ag & & Fucidin $(5 \mu \mathrm{g})$ \\
\hline Catalase & & Novobiocin $(5 \mu \mathrm{g})$ \\
\hline Oxidase & & Penicillin G (2 units) \\
\hline Arginine dihyd & & Penicillin G (10 units) \\
\hline Arginine decarb & & Methicillin $(10 \mu \mathrm{g})$ \\
\hline Ornithine decar & & Neomycin $(10 \mu \mathrm{g})$ \\
\hline Lysine decarbo & & Trimethoprim ( 1.25 units $)$ \\
\hline Trimethylammc & ide reduction & Sulphafurazole $(100 \mu \mathrm{g})$ \\
\hline Nitrate to nitri & & $0 / 129(10 \mu \mathrm{g})$ \\
\hline Nitrate to nitro & & \\
\hline Acid from inos & & \\
\hline Gas from glucc & & \\
\hline Further compo & ed as sole carbon source & for isolates $049 / 1$ and 024 \\
\hline tose & L-Rhamnose & Mannose \\
\hline ose & Maltose & Cellobiose \\
\hline ose & Melibiose & Stachyose (Sigma) \\
\hline (Oxoid) & Agarose (Sigma) & Starch (Fisons) \\
\hline in $(\mathrm{BDH})$ & Carrageenan (Sigma) & Arabinogalactan (Sigma) \\
\hline arabic (Sigma) & Gum xanthan (Sigma) & Galactomannan \\
\hline
\end{tabular}

decomposition was tested on plates of nutrient agar overlaid with a thin layer of cellulose powder suspended in nutrient agar. Plates were incubated for $14 \mathrm{~d}$ and examined for clearing of the cellulose layer around developing colonies. Trimethylamine oxide reduction was tested by the method of Laycock \& Regier (1971) except that $20 \%(\mathrm{w} / \mathrm{v}) \mathrm{KOH}$ was used in place of $20 \%(\mathrm{w} / \mathrm{v}) \mathrm{K}_{2} \mathrm{CO}_{3}$.

Carbon compounds utilized for growth. Strains were tested for their ability to utilize a range of organic compounds as sole carbon and energy source. The compounds chosen (see Table 1) included many of those used by Lee et al. (1977), Lewin (1969), Stanier (1942) and van der Meulen et al. (1974) for the differentiation of aerobic Gram-negative rods. They were added to the basal mineral medium to give a final concentration of $0.2 \%(\mathrm{w} / \mathrm{v})$ and autoclaved at $121{ }^{\circ} \mathrm{C}$ for $15 \mathrm{~min}$, with the exception of pentose sugars which were sterilized by filtration and added aseptically to autoclaved basal medium. Those organisms unable to grow on or hydrolyse gelatin were also tested on plates of the carbon source media solidified with $15 \%(\mathrm{w} / \mathrm{v})$ gelatin. Tubes were incubated at $25^{\circ} \mathrm{C}$ and plates at $20^{\circ} \mathrm{C}$ and examined daily for growth. 
Antibiotic sensitivity. Antibiotic Multodisks (Oxoid) and discs containing the vibriostat $0 / 129(10 \mu \mathrm{g})$ were applied to surface-inoculated dried plates of CM3 medium (Oxoid). Details of the antibiotics used are given in Table 1.

$D N A$ analysis. DNA was extracted and purified by the method of Mandel et al. (1971); the $T_{m}$ was determined using the method of Marmur \& Doty (1962) and the mol \% GC was calculated using the equation of De Ley (1970).

Numerical taxonomy. The results of the tests and observations listed in Table 1 were coded as binary data and the similarity matrix of similarities, calculated using the simple matching coefficient (Sneath, 1957), was sorted using McQuitty's techniques (McQuitty, 1967). Cluster analysis was carried out using the Clustan 1A package of Wishart (1969) on the University of Surrey ICL 1905F computer.

Assay of agarase activity. Selected isolates were cultured in $250 \mathrm{ml}$ Erlenmeyer flasks containing $150 \mathrm{ml}$ basal mineral medium supplemented with $0.2 \%$ (w/v) agar (Oxoid no. 3) and incubated at $25{ }^{\circ} \mathrm{C}$ for 5 to $10 \mathrm{~d}$ on a rotary shaker $\left(150 \mathrm{rev} . \mathrm{min}^{-1}\right)$. Cultures were then centrifuged to remove bacteria, the supernatant was treated with $0 \cdot 2$ vol. $2.5 \%(\mathrm{w} / \mathrm{v})$ Cetrimide and the the resulting precipitate was removed by centrifuging. The supernatant was treated with 2 vol. acetone at $0{ }^{\circ} \mathrm{C}$ and allowed to stand at $4{ }^{\circ} \mathrm{C}$ for 30 min. The precipitate was collected by centrifuging and redissolved in $5 \mathrm{~mm}-\mathrm{KH}_{2} \mathrm{PO}_{4} / \mathrm{Na}_{2} \mathrm{HPO}_{4}$ buffer (pH 6.4).

The activity of this crude extracellular agarase was assayed with a solution of agarose (Sigma; $1.25 \mathrm{mg}$ $\mathrm{ml}^{-1}$ ) in $5 \mathrm{~mm}-\mathrm{KH}_{2} \mathrm{PO}_{4} / \mathrm{Na}_{2} \mathrm{HPO}_{4}$ buffer (pH 6.4). The agarase preparation $(0.5 \mathrm{ml})$ was mixed with $0.5 \mathrm{ml}$ agarose solution and $2 \mathrm{ml} 10 \mathrm{~mm}-\mathrm{KH}_{2} \mathrm{PO}_{4} / \mathrm{Na}_{2} \mathrm{HPO}_{4}$ buffer (pH 6.4) and incubated at $28{ }^{\circ} \mathrm{C}$ for $1 \mathrm{~h}$. The reaction was stopped by adding $1 \mathrm{ml} 2 \cdot 5 \%(\mathrm{w} / \mathrm{v})$ Cetrimide and the reducing sugars were measured by the method of Dygert et al. (1965) except that any precipitate of undegraded agarose was removed by centrifuging $(2600 \mathrm{~g}$ ) for $15 \mathrm{~min}$. Blanks of substrate with no enzyme and enzyme with no substrate were treated in the same way. One unit of agarase activity was defined as the release of reducing groups equivalent to $1 \mu \mathrm{mol} \mathrm{D}$-galactose in $1 \mathrm{~h}$ at $28^{\circ} \mathrm{C}, \mathrm{pH} 6.4$.

The products of the action of the crude agarase were examined qualitatively using agarose (Sigma) as a substrate. Agarose $\left(2.5 \mathrm{mg} \mathrm{ml}{ }^{-1}\right.$ ) was dissolved in boiling $10 \mathrm{~mm}-\mathrm{KH}_{2} \mathrm{PO}_{4} / \mathrm{Na}_{2} \mathrm{HPO}_{4}$ buffer (pH 6.4), cooled to $28^{\circ} \mathrm{C}$, added to an equal volume of agarase preparation and incubated at the same temperature for $5 \mathrm{~h}$. The reaction mixture was then added to 3 vol. ethanol at $0{ }^{\circ} \mathrm{C}$, any precipitate was removed by centrifuging, and the mixture was concentrated under reduced pressure. The products were analysed on unactivated plates of cellulose MN300 (Sigma), prepared by spreading a thin layer of an aqueous suspension of cellulose $(15 \%, \mathrm{w} / \mathrm{v})$ on grease-free glass plates $(20 \times 20 \mathrm{~cm})$ and drying at room temperature for $3 \mathrm{~d}$. D-Galactose was used as a marker. Plates were developed with 1-butanol/ethanol/water $(3: 2: 2$, by vol.), dried and sprayed with the modified naphthoresorcinol reagent of Duckworth \& Yaphe (1970).

Release of reducing compounds from polysaccharides other than agar. Solutions of polysaccharides $(2 \cdot 5 \mathrm{mg}$ $\mathrm{ml}^{-1}$ ) were prepared in $10 \mathrm{~mm}-\mathrm{KH}_{2} \mathrm{PO}_{4} / \mathrm{Na}_{2} \mathrm{HPO}_{4}$ buffer $(\mathrm{pH} \mathrm{6.4)} \mathrm{(see} \mathrm{Table} \mathrm{7).} \mathrm{The} \mathrm{substrate}(0.5 \mathrm{ml})$ was added to either a preparation of crude agarase $(0.5 \mathrm{ml})$ or buffer $(0.5 \mathrm{ml})$ and incubated at $28^{\circ} \mathrm{C}$ for $1 \mathrm{~h}$. The reaction was stopped by adding $2 \cdot 5 \%(\mathrm{w} / \mathrm{v})$ Cetrimide $(1 \mathrm{ml})$, and the mixture was clarified by centrifuging and assayed for reducing compounds by the method of Dygert et al. (1965).

Assay of $\alpha$-and $\beta$-galactosidase activities. The enzyme preparation $(0.5 \mathrm{ml})$ was mixed with $0.5 \mathrm{ml}$ of either $15 \mathrm{~mm}$ - $o$-nitrophenyl- $\alpha$-D-galactopyranoside or $20 \mathrm{~mm}$ - $o$-nitrophenyl- $\beta$-D-galactopyranoside in $5 \mathrm{~mm}$ $\mathrm{KH}_{2} \mathrm{PO}_{4} / \mathrm{Na}_{2} \mathrm{HPO}_{4}$ buffer $(\mathrm{pH} \mathrm{7.0})$ and incubated at $28^{\circ} \mathrm{C}$. The reaction was stopped after $1 \mathrm{~h}$, or in some cases after $24 \mathrm{~h}$, by adding 5 drops of $1.0 \mathrm{M}-\mathrm{Na}_{2} \mathrm{CO}_{3}$, and the yellow colour of the $o$-nitrophenol released was measured at $420 \mathrm{~nm}$. Blanks containing substrate but no enzyme were treated in the same manner.

Repression and induction of agarase. The production of extracellular agarase by the isolates $049 / 1$ and 024 was examined using a number of different carbohydrates and carbohydrate derivatives as carbon sources (see Table 6). Media were prepared by adding $10 \mathrm{ml}$ of an aqueous solution or homogenized suspension of the carbon source $(2 \%, \mathrm{w} / \mathrm{v}$, except gum xanthan which was $1 \%, \mathrm{w} / \mathrm{v})$ to $100 \mathrm{ml}$ of a basal medium (in $250 \mathrm{ml}$ Erlenmeyer flasks) containing (\%,w/v): $\mathrm{KNO}_{3}(0 \cdot 2) ; \mathrm{MnSO}_{4} \cdot 4 \mathrm{H}_{2} \mathrm{O}(0 \cdot 02) ; \mathrm{MgCl}_{2}$ (0.02); $\mathrm{FeSO}_{4} .7 \mathrm{H}_{2} \mathrm{O}(0.001)$; adjusted to $\mathrm{pH} 7.2$ with $0.2 \mathrm{M}-\mathrm{K}_{2} \mathrm{HPO}_{4}$ and autoclaved at $121{ }^{\circ} \mathrm{C}$ for $15 \mathrm{~min}$ (except arabinogalactan which was sterilized separately by filtration before adding to autoclaved basal medium). Flasks were inoculated with $2 \mathrm{ml}$ of $48 \mathrm{~h}$ culture in peptone water $(0.05 \%$, w/v) and incubated on a rotary shaker $\left(150 \mathrm{rev}, \mathrm{min}^{-1}\right)$ at $25^{\circ} \mathrm{C}$.

Samples $(5 \mathrm{ml})$ were removed after $1,2,5$ and $7 \mathrm{~d}$, centrifuged to remove bacteria, the supernatant was treated with $1 \mathrm{ml} 2 \cdot 5 \%(\mathrm{w} / \mathrm{v})$ Cetrimide and any precipitate was removed by centrifuging. The supernatant was then treated with 2 vol. cold $\left(4^{\circ} \mathrm{C}\right)$ acetone and the resulting precipitate was recovered by centrifuging and redissolved in $2.5 \mathrm{ml} 5 \mathrm{mM}-\mathrm{KH}_{2} \mathrm{PO}_{4} / \mathrm{Na}_{2} \mathrm{HPO}_{4}$ buffer (pH 6.4). This preparation was assayed for agarase activity as previously described. 


\section{RESULTS}

The total viable count varied from $10^{4}$ to $10^{5}$ colony-forming units during the sampling period; the maximum counts were recorded from samples taken near the silt/water interface (Table 2). Agar-degrading bacteria were detected in relatively few enriched samples, mostly in those taken near the silt/water interface during summer (Table 3 ). No strains able to liquefy or soften agar were isolated from the surface waters. Isolates changing the structure of agar so that it no longer turned a deep reddish violet with Lugol's iodine, but not softening or liquefying it, were found at all depths. Because this character was found to be unstable, such isolates were not studied in more detail.

When the mutual similarity indices of Sneath (1957), based on 70 morphological and biochemical observations, were plotted as a dendrogram (Fig. 2), the organisms divided into three groups at the $80 \%$ similarity level. Group A included all the non-pigmented, agar-liquefying isolates with NCMB 1914 and NCIB 9491, group B contained only the yellow-pigmented, agar-softening isolates and group C contained NCIB 10472 and NCIB 8768.

\section{Colourless, agar-liquefying strains (group A)}

Apart from minor differences, all 11 non-pigmented, agar-liquefying isolates were very similar and almost certainly belong to the same species. Colonies were white and rapidly produced a crater of digested agar on nutrient agar plates, in the manner illustrated by v. Hofsten \& Malmqvist (1975). Moist nutrient agar plates were completely liquefied in about $10 \mathrm{~d}$ at $25^{\circ} \mathrm{C}$. Colonies produced no diffusible pigment and growth occurred over a wide temperature range $\left(4\right.$ to $40^{\circ} \mathrm{C}$ ) with the optimum at $25^{\circ} \mathrm{C}$.

All strains were aerobic, oxidase, DNAase and phosphatase positive, methyl red, VogesProskauer and arginine dihydrolase negative, resistant to the vibriostat $0 / 129$ and 2 units of benzylpenicillin, sensitive to 10 units of benzylpenicillin, polymyxin (300 units), novobiocin $(5 \mu \mathrm{g})$ and chloramphenicol $(10 \mu \mathrm{g})$, utilized D-xylose, L-arabinose, L-rhamnose, $\mathrm{D}$-glucose, D-galactose, D-mannose, D-fructose, sucrose, trehalose, maltose, cellobiose, lactose, melibiose, raffinose, glucosamine, $N$-acetylglucosamine, agar, agarose, carrageenan, arabinogalactan, galactomannan, gum arabic, gum xanthan and cellulose as sole carbon source, and reduced nitrate to nitrite. No strain hydrolysed gelatin or starch, produced indole or $\mathrm{H}_{2} \mathrm{~S}$ or reduced trimethylamine oxide.

Some strains (3/11) were weakly catalase positive, the rest being negative, and their reaction in the traditional $\mathrm{O} / \mathrm{F}$ test was ambiguous, difficult to assess and was usually scored as weakly oxidative or non-reactive. Distinct acid production was observed on plates of Hugh \& Leifson medium incubated aerobically, but not on plates incubated anaerobically on which no growth occurred.

Strains were vigorously motile and had a single polar flagellum. They showed no special requirement for $\mathrm{Na}^{+}$and were inhibited in the presence of more than $2 \% \mathrm{NaCl}$. Considered as pseudomonads, these isolates most closely resemble phenon $\mathrm{E}$ of Lee et al. (1977) except that they were unable to reduce trimethylamine oxide or produce $\mathrm{H}_{2} \mathrm{~S}$. The mol $\%$ GC of three representative strains was $50 \cdot 8,50 \cdot 3$ and $50 \cdot 8$. It is suggested that the strains of group A belong to the genus Alteromonas as redefined by Lee et al. (1977). Despite some significant differences, our isolates are very closely related to, and probably belong to the same species as, NCMB 1914.

Vibrio agarliquefaciens (Bergey et al., 1934), first described as Microspira agarliquefaciens by Gray \& Chalmers (1924), is of uncertain affinity and might also be con-specific with the isolates described in this paper. Thus we decline from proposing a new name for them because the existing epithet 'agarliquefaciens' may be applicable. We have not examined $V$. agarliquefaciens and further work is required to establish whether it belongs to Alteromonas. A representative of our isolates $(049 / 1)$ has been deposited with the National 
Table 2. Counts of colony-forming units (c.f.u.) on 0.25NA at different depths of some of the deeper, and possibly stratified, stretches of the River Wev during the period March to November 1976

$\begin{array}{crrrrrrrrr}\begin{array}{c}\text { Depth } \\ \text { (cm) }\end{array} & \text { Mar } & \text { Apr } & \text { May } & \text { Jun } & \text { Jul } & \text { Aug } & \text { Sept } & \text { Oct } & \text { Nov } \\ 30 & 20 \cdot 3 & 16 \cdot 3 & 9 \cdot 3 & 7 \cdot 5 & 4 \cdot 5 & 4 \cdot 9 & 4 \cdot 0 & 2 \cdot 5 & 4 \cdot 8 \\ 60 & 15 \cdot 8 & 13 \cdot 0 & 8 \cdot 3 & 5 \cdot 0 & 4 \cdot 1 & 2 \cdot 9 & \text { ND } & 1 \cdot 9 & \text { ND } \\ 90 & 7 \cdot 8 & 11 \cdot 5 & 6 \cdot 9 & 2 \cdot 5 & 2 \cdot 9 & 2 \cdot 2 & 2 \cdot 6 & 1 \cdot 8 & 2 \cdot 3 \\ 120 & 7 \cdot 3 & 4 \cdot 3 & 5 \cdot 5 & 2 \cdot 1 & 2 \cdot 1 & \text { ND } & 1 \cdot 8 & 1 \cdot 8 & 2 \cdot 5 \\ 150 & 20 \cdot 0 & 1 \cdot 5 & 9 \cdot 0 & 2 \cdot 8 & 2 \cdot 8 & 2 \cdot 9 & 3 \cdot 2 & \text { ND } & 2 \cdot 9 \\ 180 & 23 \cdot 0 & 21 \cdot 1 & 12 \cdot 3 & 8 \cdot 2 & 5 \cdot 3 & \text { ND } & \text { ND } & 3 \cdot 0 & \text { ND } \\ \text { Bottom } & 45 \cdot 0 & 40.5 & 37 \cdot 3 & 15 \cdot 1 & 10 \cdot 7 & 11 \cdot 7 & 11 \cdot 6 & 25 \cdot 0 & 11 \cdot 8\end{array}$

ND, Not determined.

* Each value is based on at least 10 , and usually 15 , samples from each depth. Table 3. Number of samples (taken from the River Wey) from which
agar-degrading bacteria were detected after enrichment

\begin{tabular}{rccccccccccr}
$\begin{array}{c}\text { Depth } \\
(\mathrm{cm})\end{array}$ & Reaction & \multicolumn{1}{c}{ Mar } & Apr & May & Jun & Jul & Aug & Sept & Oct & Nov & Total \\
30 & G & 0 & 4 & 1 & 0 & 0 & 2 & 2 & 0 & 0 & 9 \\
60 & S & 0 & 0 & 0 & 2 & 0 & 0 & 1 & 0 & 1 & 4 \\
& G & 2 & 0 & 2 & 3 & 2 & 1 & 3 & 0 & 3 & 16 \\
120 & S & 0 & 0 & 1 & 1 & 0 & 0 & 0 & 1 & 0 & 3 \\
& G & 0 & 2 & 1 & 4 & 1 & 0 & 2 & 2 & 0 & 12 \\
180 & L & 0 & 0 & 0 & 2 & 1 & 0 & 0 & 0 & 0 & 3 \\
& S & 0 & 1 & 0 & 3 & 2 & 3 & 2 & 2 & 1 & 14 \\
& G & 3 & 4 & 3 & 8 & 5 & 2 & 2 & 2 & 2 & 31 \\
Bottom & L & 0 & 0 & 2 & 4 & 0 & 0 & ND & 0 & 0 & 6 \\
& S & 0 & 0 & 2 & 6 & 1 & 1 & ND & 0 & 0 & 10 \\
& G & 6 & 4 & 8 & 7 & 5 & 4 & ND & 3 & 2 & 39
\end{tabular}

ND, Not determined.

* Number of samples from each depth was 10 in March and April and 15 at all other times.

$\dagger$ L, Liquefaction; S, softening; G, 'gelase' reaction with iodine. No samples from $<180 \mathrm{~cm}$ depth showed liquefaction and no samples from $<60 \mathrm{~cm}$ showed softening.

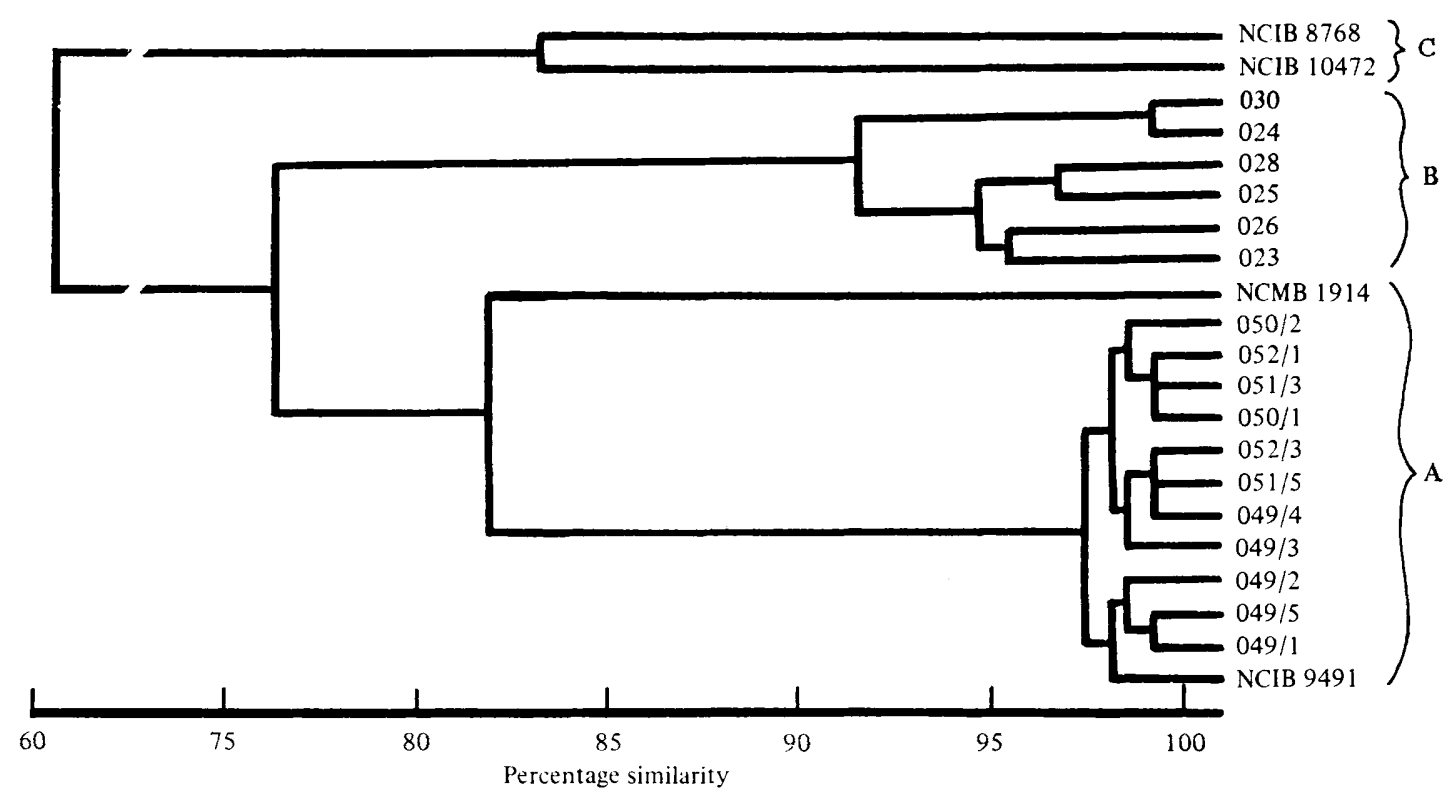

Fig. 2. Dendrogram based on mutual similarity indices $(S)$ computed from 70 observations on 17 isolates and 4 culture collection strains. 
Table 4. Comparison of the agar-liquefying isolates NCMB 2062 (this paper), NCMB 1914 (v. Hofsten \& Malmqvist, 1975) and Microspira agarliquefaciens (Gray \& Chalmers, 1924)

\begin{tabular}{|c|c|c|c|}
\hline Character & $\begin{array}{c}\text { NCMB } 2062 \\
(049 / 1)\end{array}$ & NCMB 1914 & $\begin{array}{c}\text { Microspira } \\
\text { agarliquefaciens* }\end{array}$ \\
\hline Shape & Straight to curved rods & Slightly curved rods & Short curved rods \\
\hline Size $(\mu \mathrm{m})$ & $0.5-0.7 \times 2.0-3.0$ & $0.5 \times 1.7$ & $0.6-1.2 \times 1.4-3.0$ \\
\hline Flagella & Single polar & Single polar & Single polar \\
\hline $\mathrm{O}_{2}$ requirement & Highly aerobic & Highly aerobic & Highly aerobic \\
\hline $\mathrm{NO}_{3}^{-} \rightarrow \mathrm{NO}_{2}^{-}$ & + & + & + \\
\hline \multicolumn{4}{|l|}{ Growth at: } \\
\hline $16^{\circ} \mathrm{C}$ & + & $?$ & + \\
\hline $25^{\circ} \mathrm{C}$ & ++ & ++ & ++ \\
\hline $37^{\circ} \mathrm{C}$ & + & + & - \\
\hline Cellulolysis & + & - & + \\
\hline Gelatin liquefaction & - & - & - \\
\hline Amylase & - & - & + \\
\hline \multicolumn{4}{|l|}{ Growth on: } \\
\hline Glucose & + & + & + \\
\hline Sucrose & + & $?$ & + \\
\hline Lactose & + & + & + \\
\hline Maltose & + & + & + \\
\hline Glycerol & - & - & - \\
\hline
\end{tabular}

Collection of Marine Bacteria, Torry Research Station, Aberdeen, as NCMB 2062. Some properties of this isolate, those of NCMB 1914, and those described by Gray \& Chalmers (1924) for Microspira agarliquefaciens are compared in Table 4.

Pigmented, agar-softening isolates (group B)

Two of the six original isolates in this group (025 and 026) lost their agarolytic activity after several subcultures and the following description is based on the remaining four $(023,024,028$ and 030$)$. All strains produced discrete yellow colonies surrounded by a shallow depression on nutrient agar. After 5 to $10 \mathrm{~d}$ the agar gel was obviously softened but did not liquefy. Colonies were positive in the iodine test, a character which was reproducible after many subcultures (Fig. 3). Colonies remained circular and discrete on nutrient agar but limited spreading was observed on river water agar and basal mineral medium agar if the agar surface was sufficiently moist. Strains grew between 4 and $30^{\circ} \mathrm{C}$ with the optimum at $25^{\circ} \mathrm{C}$.

The bacteria were Gram-negative, non-motile and showed considerable pleomorphism with coccoid, long slender, and constricted forms occurring in all strains (Fig. 4). The constricted forms were reminiscent of those illustrated by Mitchell et al. (1969) and considered by them to be characteristic of species of Cytophaga. Pleomorphism was more common in cultures from solid media and long slender forms predominated in cultures in liquid media. Bacteria taken from $24 \mathrm{~h}$-old colonies grown on solid media frequently showed periplasmic strands similar to structures observed on cell surfaces of Cytophaga johnsonae by Follett \& Webley (1965). Strains did not show flexing movement in hanging drop preparations but very slow gliding motility was observed at areas of contact between the meniscus of the drop and the supporting cover slip. These bacteria did not stain well and microcysts were never observed in stained preparations.

All isolates grew well in media free of $\mathrm{NaCl}$, poorly with $2 \% \mathrm{NaCl}$, and not at all at higher concentrations. The four isolates were sufficiently similar to be considered members of the same species and, despite the difficulty in observing gliding motility coupled with the production of compact, discrete colonies rather than thin spreading colonies, they fit well into the genus Cytophaga. With the exception of the freshwater isolate Cytophaga 

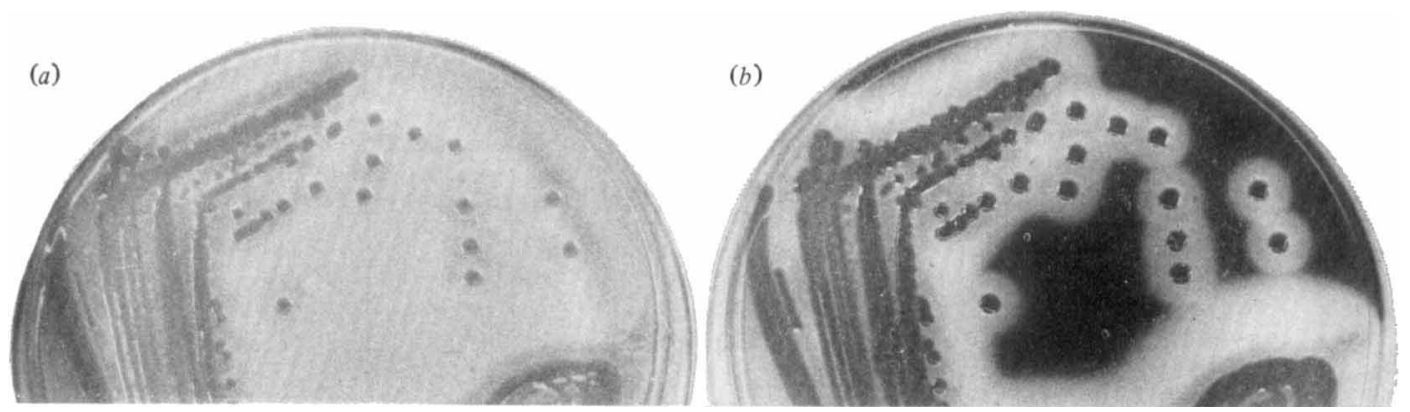

Fig. 3. Nutrient agar plate inoculated with Cytophaga saccharophila before $(a)$ and after $(b)$ flooding with Lugol's iodine. Depressions in the agar can just be seen before treatment with iodine which exposes the extent of the 'gelase' reaction.
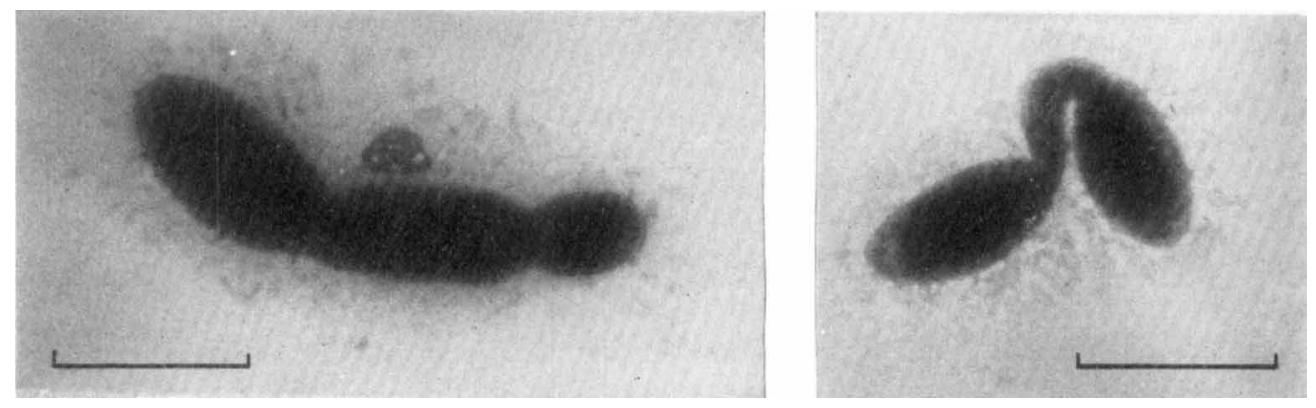

Fig. 4. Electron micrographs of Cytophaga saccharophila negatively stained with $2 \%(\mathrm{w} / \mathrm{v})$ phosphotungstic acid. Bar markers represent $1 \mu \mathrm{m}$.

flevensis (van der Meulen et al., 1974), all adequately described agarolytic species of Cytophaga have been isolated from marine habitats. Our isolates differ from $C$. flevensis in their ability to hydrolyse starch, gelatin and carrageenan and to utilize cellobiose and trehalose as sources of carbon and energy. Flavobacterium pectinovorum (Dorey, 1959), considered by Mitchell et al. (1969) to be a species of Cytophaga and by Christensen (1977a) to be synonymous with $C$. johnsonae, hydrolyses both starch and gelatin but not agar.

Flavobacterium meningosepticum, which may also be a species of Cytophaga (Mitchell et al., 1969), and Flavobacterium group IIb (Owen \& Lapage, 1974) have a mol \% GC of 36 to 38 , which is close to that of the isolates described in this paper, but they differ from our isolates in a number of other respects (Table 5). Flavobacterium sp. NCIB 9491, considered by Mitchell et al. (1969) to be of uncertain taxonomic affinity, has a mol \% GC of 51.2 and, in our experience, is actively motile and liquefies agar. It seems to be more closely related to Alteromonas than to Cytophaga (Fig. 2) and produces rather dull, greyishyellow colonies.

In view of these differences from adequately described species, and the wide range of carbohydrates which our isolates are able to utilize, we suggest that they belong to a distinct species for which we give the following name and description.

Cytophaga saccharophila sp.nov.

sac.cha.ro.phi'la Gr.n. sacchar sugar; Gr.adj. philus loving; M.L.fem.adj. saccharophila sugar loving.

Gram-negative rods, 2.5 to $6.0 \times 0.5$ to $0.7 \mu \mathrm{m}$ occurring singly or in small clumps. In older cultures, especially on solid media, coccoid and constricted forms occur. In liquid culture, slender rods and filamentous forms predominate. Microcyst formation has not 
Table 5. Comparison of Cytophaga saccharophila with Flavobacterium meningosepticum and Flavobacterium group IIb

\begin{tabular}{|c|c|c|c|}
\hline Character & $\begin{array}{l}\text { Flavobacterium } \\
\text { group IIb } \\
\text { NCTC 10797* }\end{array}$ & $\begin{array}{l}\text { Flavobacterium } \\
\text { meningosepticum } \\
\text { NCTC 10588* }\end{array}$ & $\begin{array}{c}\text { Cytophaga } \\
\text { saccharophila }\end{array}$ \\
\hline Base composition (mol \% GC) & $36 \cdot 1$ & $36 \cdot 1$ & $36 \cdot 1-36 \cdot 3$ \\
\hline Anaerobic growth & + & + & - \\
\hline Aerobic growth & + & + & + \\
\hline Pigment & Orange-yellow & Yellow & Yellow \\
\hline Growth at $22{ }^{\circ} \mathrm{C}$ & + & + & + \\
\hline Growth at $37^{\circ} \mathrm{C}$ & + & + & - \\
\hline Indole & + & + & - \\
\hline Phosphatase & + & + & + \\
\hline $\mathrm{H}_{2} \mathrm{~S}$ production & + & + & + \\
\hline \multicolumn{4}{|l|}{ Sensitivity to: } \\
\hline Penicillin (2 units) & - & - & - \\
\hline Polymyxin (300 units) & - & - & - \\
\hline Nitrate reduction & - & + & + \\
\hline Starch hydrolysis & - & + & + \\
\hline Gelatin hydrolysis & - & - & + \\
\hline Agarolytic activity & - & - & + \\
\hline
\end{tabular}

* Data from Owen \& Lapage (1974).

been observed. Flagella are absent but gliding motility may be observed when cells are in contact with surfaces.

Colonies on nutrient agar are 1 to $2 \mathrm{~mm}$ in diameter, convex, glistening, slimy, yellow and opaque becoming translucent with age, especially at the periphery. On moist media spreading may be observed but normally colonies are sunken in shallow hollows as a result of their agarolytic activity.

Obligately aerobic, oxidase positive, strongly catalase positive, metabolizing glucose oxidatively in the Hugh \& Leifson O/F test. Acetylmethylcarbinol and indole are not produced and the methyl red test is negative. Starch and gelatin are both hydrolysed and all strains examined are phosphatase positive and DNAase negative. Hydrogen sulphide is produced from triple sugar iron agar.

The following carbohydrates may be used as sole carbon and energy source: D-glucose, D-galactose, D-fructose, D-mannose, D-xylose, L-arabinose, L-rhamnose, lactose, sucrose, maltose, cellobiose, melibiose, trehalose, raffinose, stachyose. A number of polysaccharides may also form the sole carbon and energy source: agar, agarose, starch, pectin, carrageenan, arabinogalactan, gum arabic, gum xanthan and galactomannan.

Nitrate is reduced to nitrite by 3 out of 4 strains. All isolates so far studied are sensitive to tetracycline $(10 \mu \mathrm{g})$, streptomycin $(10 \mu \mathrm{g})$, fucidin $(5 \mu \mathrm{g})$, novobiocin $(5 \mu \mathrm{g}), 0 / 129(10 \mu \mathrm{g})$ and benzylpenicillin (10 units) but are resistant to polymyxin B (300 units), chloramphenicol $(10 \mu \mathrm{g})$ and neomycin $(10 \mu \mathrm{g})$. Concentrations of antibiotic are given as quantities per disc using a Multodisk assay.

Agarolytic activity

The agarolytic activity of both types of organism was repressed in the presence of glucose or galactose. Agarase appeared to be inducible, not only by agar, but by a range of polysaccharides (Table 6).

The crude extracellular agarase preparations from the Alteromonas and Cytophaga species differed in the nature of the most readily demonstrable end products. The Alteromonas species gave a product with the same chromatographic properties as galactose whereas the Cytophaga species gave a complex mixture of breakdown products corresponding to oligosaccharides in their chromatographic behaviour. Both preparations could release reducing compounds from a number of polysaccharides other than agar (Table 7). Studies 
Table 6. Induction of 'agarase' activity in Alteromonas sp. (049/1) and Cytophaga saccharophila (024) by a number of carbohydrate derivatives when present as the sole carbon source

\begin{tabular}{lcc} 
& $\begin{array}{c}\text { Agarolytic activity relative to that } \\
\text { produced when agar was the } \\
\text { carbon source }\end{array}$ \\
Carbon source & \multicolumn{1}{c}{$\begin{array}{c}\text { Cytophaga } \\
\text { saccharophila }\end{array}$} \\
Agar & $(049 / 1)$ & $(024)$ \\
Glucose & 1.000 & 1.000 \\
Starch & 0.000 & 0.000 \\
Galactomannan & 0.045 & 2.577 \\
Pectin & 0.824 & 1.080 \\
Cellulose & 0.094 & 2.577 \\
Stachyose & 0.211 & 0.998 \\
Raffinose & 0.059 & 0.748 \\
Melibiose & 0.056 & 1.000 \\
Arabinogalactan & 0.069 & 0.582 \\
Gum arabic & 0.978 & 2.995 \\
Gum xanthan & 0.640 & 1.000 \\
Oakwood leachate & 0.577 & 1.496 \\
& 0.282 & 3.159
\end{tabular}

Table 7. Production of reducing compounds, as determined by the neocuproine method, by the 'agarases' of Alteromonas sp. (049/1) and Cytophaga saccharophila (024)

\begin{tabular}{|c|c|c|}
\hline \multirow[b]{2}{*}{ Substrate } & \multicolumn{2}{|c|}{$\begin{array}{l}\text { Reducing material released from } \\
1.25 \text { mg substrate } \\
\text { (as } \mu \text { mol galactose } \mathrm{h}^{-1} \text { ) by the } \\
\text { partially purified agarase of: }\end{array}$} \\
\hline & $\begin{array}{c}\text { Alteromonas sp. } \\
(049 / 1)\end{array}$ & $\begin{array}{l}\text { Cytophaga } \\
\text { saccharophila } \\
\quad(024)\end{array}$ \\
\hline Agar & $33 \cdot 33$ & $8 \cdot 57$ \\
\hline Agarose & $34 \cdot 29$ & $5 \cdot 71$ \\
\hline Galactomannan & 0.48 & $8 \cdot 57$ \\
\hline Starch & 0.09 & $5 \cdot 24$ \\
\hline Pectin & 0.00 & 6.67 \\
\hline Carboxymethylcellulose & $17 \cdot 14$ & $3 \cdot 81$ \\
\hline Gum arabic & $22 \cdot 86$ & $3 \cdot 81$ \\
\hline Gum xanthan & $24 \cdot 76$ & $4 \cdot 29$ \\
\hline Stachyose & $1 \cdot 43$ & $3 \cdot 33$ \\
\hline Arabinogalactan & $23 \cdot 80$ & 3.00 \\
\hline Melibiose & 0.00 & $1 \cdot 90$ \\
\hline Raffinose & 0.95 & $5 \cdot 24$ \\
\hline$o$-Nitrophenyl- $\alpha$-D-galactoside & 0.00 & $8 \cdot 57$ \\
\hline$o$-Nitrophenyl- $\beta$-D-galactoside & $0 \cdot 00$ & $1 \cdot 90$ \\
\hline$o$-Nitrophenyl- $\beta$-D-glucoside & 0.00 & $1 \cdot 90$ \\
\hline
\end{tabular}

using preparations of 'agarases' from these freshwater isolates, which have been fractionated by a variety of methods, have confirmed that they retain their ability to hydrolyse a range of polysaccharides other than agar although it is still possible that such preparations contain a mixture of polysaccharidases rather than a single enzyme with a wide substrate specificity.

The two $o$-nitrophenylgalactosides were very poor substrates although both $\alpha$ - and $\beta$-galactosidase activities could be detected in preparations from both organisms. The results of studies on the purification and properties of the two types of 'agarase' activity will be reported in a further communication. 


\section{DISCUSSION}

Although most agarolytic bacteria described have been isolated from marine sources, there are reports that they also occur in soil and freshwater, e.g. Cytophaga flevensis from water and Bacillus agar-exedens from soil. Indeed, Nicol (1931), having noticed the presence of agar-softening, yellow-pigmented bacteria from a swampy soil in Palmer's Green, London, observed that it seemed likely that the discovery of such bacteria would be more widespread if they were looked for.

There can be little doubt that agar-degrading bacteria play an important role in the recycling of organic material at the edges of the seas and oceans where agar forms a significant constituent of the polysaccharides of the red algae. When such organisms have been isolated from non-marine habitats, attempts have been made to rationalize their presence by looking for agar in the environment or by relating the environment to a recent marine origin. Thus, v. Hofsten \& Malmqvist (1975) isolated their strongly agarolytic organism from a sewage treatment plant which they suggest receives quantities of agar laboratory wastes. Although agar as an environmental pollutant could have some selective effect it is probable that agarolytic organisms were present, and had a role to play, in the habitat before the appearance of the pollutant. The isolation of Cytophaga flevensis from the IJsselmeer is discussed by van der Meulen (1975) in the context of the recent marine origin of the IJsselmeer and the presence of Bangia fuscopurpurea, a red alga adapted to fresh water. Like the organisms described in this paper, the isolates from the Swedish sewage effluent and from the IJsselmeer cannot grow in the presence of more than $2 \% \mathrm{NaCl}$ and show no particular salt requirement. As Christensen (1977b) pointed out, 'This low salt tolerance would argue against it ( $C$. flevensis) being a relict from the marine period and indicates instead that it is more likely to be the first non-marine agar-decomposing Cytophaga'.

In lowland rivers, such as the River Wey, a large part of the organic material will be polymers of plant origin, both allochthonous material from terrestrial plants including trees, and autochthonous material from aquatic plants including algae. Although in several respects the structure of agar is unique, it is one of many plant polysaccharides containing D-galactose. Such compounds occur in the hemicellulose fraction of plant cell walls, the pectin fraction of the middle lamella and the gums of plant exudates. None of these contains the derivatives of L-galactose present in the polysaccharides of agar but it is conceivable that some of the micro-organisms able to degrade these polymers could also degrade agar.

Our studies have shown that the 'agarases' from two taxonomically distinct agar-degrading isolates from freshwater can also degrade other polysaccharides and are inducible by the presence of polysaccharides other than agar.

Van der Meulen \& Harder $(1975,1976 a, b)$ found that the agarase of Cytophaga flevensis was very specific, hydrolysing agar, agarose and agaropectin but not porphyran, carrageenans, pectin, polygalactoaraban, inulin or amylose. The formation of agarase by this organism is, however, induced by melibiose as well as by agar and the oligosaccharides associated with it (van der Meulen \& Harder, 1975). The 'agarase' of Cytophaga saccharophila would seem to differ from that of $C$. flevensis, both in its range of substrates and in being inducible by a number of polysaccharides and oligosaccharides. Further study is needed to discover whether the polysaccharidase activity of $C$. saccharophila is associated with the same enzyme complex or is a reflection of the presence of a mixture of distinct enzymes.

It is unlikely that $C$. saccharophila and the agarolytic Alteromonas sp. had been in contact with agar before their isolation in the laboratory. Their low salt tolerance rules out the possibility that they are marine organisms recently adapted to a freshwater 
environment. We therefore propose the alternative hypothesis that the agarolytic activity of these isolates is a reflection of their ability to break down a wide range of polysaccharides including many heteropolysaccharides containing D-galactose.

We thank Miss Dawn Chescoe of the Structural Studies Unit, University of Surrey, for help in the preparation of the electron micrographs, Dr G. Hobbs, Dr D. M. Gibson, Miss M. Hendrie and Dr J. M. Shewan of Torry Research Station for helpful discussions and for assistance in the determination of the \% GC compositions. The work described was carried out during the tenure of a travelling scholarship awarded to J.A.C.A. by the University of Nigeria.

\section{REFERENCES}

ARAKl, C. (1937). Chemical studies of agar-agar. III. Acetylation of agar-like substances from Gelidium amansii. Journal of the Chemical Society of Japan 58, 1338-1350.

ARAKI, C. (1956). Structures of agarose constituents of agar-agar. Bulletin of the Chemical Society of Japan 29, 543-544.

Bergey, D. H., Breed, R. S., Hammer, B. W., Huntoon, F. M., Murray, E. G. D. \& Harrison, F. C. (1934). Bergey's Manual of Determinative Bacteriology, 4th edn. Baltimore: Williams \& Wilkins.

Buchanan, R. E. \& GibBons, N. E. (1974). Bergey's Manual of Determinative Bacteriology, 8th edn. Baltimore: Williams \& Wilkins.

Christensen, P. J. (1977a). Synonymy of Flavobacterium pectinovorum Dorey with Cytophaga johnsonae Stanier. International Journal of Systematic Bacteriology 27, 122-132.

Christensen, P. J. (1977b). The history, biology and taxonomy of the Cytophaga group. Canadian Journal of Microbiology 23, 1599-1653.

CowAN, S. T. \& STEEL, K. J. (1974). Manual for the Identification of Medical Bacteria, 2nd edn. Cambridge: Cambridge University Press.

DE LEY, J. (1970). Re-examination of the association between melting points, buoyant density and chemical base composition of deoxyribonucleic acid. Journal of Bacteriology 101, 738-754.

DOREY, M. J. (1959). Some properties of a pectolytic soil flavobacterium. Journal of General Microbiology 20, 91-104.

Duckworth, M. \& Yaphe, W. (1970). Thin-layer chromatographic analysis of enzymic hydrolysates of agar. Journal of Chromatography 49, 482-487.

Duckworth, M. \& YAPHe, W. (1971a). The structure of agar. I. Fractionation of a complex mixture of polysaccharides. Carbohydrate Research 16, 189-197.

Duckworth, M. \& YAPHE, W. $(1971 b)$. The structure of agar. II. The use of bacterial agarase to elucidate structural features of the charged polysaccharide in agar. Carbohydrate Research 16, 435-445.

Dygert, S., Li, L., Florida, D. \& Thoma, J. A. (1965). Determination of reducing sugar with improved precision. Analytical Biochemistry 13, 367-374.

Follett, E. A. C. \& Webley, D. M. (1965). An electron microscope study of the cell surface of Cytophaga johnsonae and some observations on related organisms. Antonie van Leeuwenhoek 31, 361-382.

GraN, H. H. (1902). Studien über Meeresbakterien. II. Ueber die Hydrolysis des Agar durch ein neues Enzyme die Gelase. Bergen Museums Aarbog, No. 2. [Cited in Stanier, R. Y. (1941). Studies on marine agar-digesting bacteria. Journal of Bacteriology 42, 527-559.]

Gray, P. H. H. \& Chalmers, C. H. (1924). On the stimulating action of certain organic compounds on cellulose decomposition by means of a new aerobic micro-organism that attacks both cellulose and agar. Annals of Applied Biology 11, 324-338.

v. Hofsten, B. \& MAlmQvist, M. (1975). Degradation of agar by a Gram-negative bacterium. Journal of General Microbiology 87, 150-158.

Hugh, R. \& Leifson, E. (1953). The taxonomic significance of fermentative versus oxidative metabolism of carbohydrates by various Gram-negative bacteria. Journal of Bacteriology 66, 24-26.

Hunger, W. \& Claús, D. (1978). Reisolation and growth of Bacillus agar-exedens. Antonie van Leeuwenhoek 44, 105-113.

IzUMI, K. (1972). Chemical heterogeneity of the agar from Gracilaria verrucosa. Journal of Biochemistry 72, 135-140.

Jefries, C. D., Holtman, D. F. \& Guse, D. G. (1957). Rapid method for determining the activity of micro-organisms on nucleic acids. Journal of Bacteriology 73, 590-591.

KING, E. O., WARD, M. K. \& RANEY, D. E. (1954). Two simple media for the demonstration of pyocyanin and fluorescein. Journal of Laboratory and Clinical Medicine 44, 301.

Kovacs, N. (1956). Identification of Pseudomonas pyocyanea by the oxidase reaction. Nature, London 178, 703.

LAYCOCK, R. H. \& REGIER, L. W. (1971). Trimethylamine-producing bacteria on haddock (Melanorgramas aeglifinus) fillets during refrigerated storage. Journal of the Fisheries Research Board of Canada 28, 305-307.

LeE, J. V., Gibson, D. M. \& Shewan, J. M. (1977). A numerical taxonomic study of some pseudomonas-like marine bacteria. Journal of General Microbiology 98, 439-451.

LewiN, R. A. (1969). A classification of flexibacteria. Journal of General Microbiology 58, 189-206.

Mandel, M., Leadbetter, E. R., Pfennig, N. \& TruPER, H. G. (1971). Deoxyribonucleic acid base composition of phototrophic bacteria. 
International Journal of Systematic Bacteriology 21, 222-230.

MARMUR, J. \& Doty, P. (1962). Determination of the base composition of deoxyribonucleic acid from its thermal denaturation temperature. Journal of Molecular Biology 5, 109-118.

McQuitTy, L. L. (1967). A mutual development of some typological theories and pattern-analytic methods. Educational and Psychological Measurement 27, 21-46.

VAN DER MEULEN, H. J. (1975). The enzymic hydrolysis of agar by Cytophaga flevensis sp.nov. Ph.D. thesis, University of Groningen, The Netherlands.

VAN DER Meulen, H. J. \& HARDer, W. (1975). Production and characterization of the agarase of Cytophaga flevensis. Antonie van Leeuwenhoek 41, 431-447.

VAN DER MEUleN, H. J. \& HARDER, W. (1976a). The regulation of agarase production by resting cells of Cytophaga flevensis. Antonie van Leeuwenhoek 42, 277-286.

VAN DER Meulen, H. J. \& HARder, W. (1976b). Characterization of the neoagarotetra-ase and neoagarobiase of Cytophaga flevensis. Antonie van Leeuwenhoek 42, 81-94.

van der Meulen, H. J., Harder, W. \& VeldKamp, H. (1974). Isolation and characterization of Cytophaga flevensis sp.n., a new agarolytic flexibacterium. Antonie van Leeuwenhoek 40, 329-346.

Mitchell, T. G., Hendrie, M. S. \& Shewan, J. M. (1969). The taxonomy, differentiation and identification of Cytophaga species. Journal of Appliea Bacteriology 32, 40-50.

Møller, V. (1955). Simplified tests for amino acid decarboxylases and for the arginine hydrolase system. Acta pathologica et microbiologica scandinavica 36, 158-172.

NG YING KIN, N. M. K. \& YAPHE, W. (1972). Properties of agar: parameters affecting gel formation and the agarase-iodine reaction. Carbohydrate Research 25, 379-385.
Nicol, H. (1931). Distribution of agar-liquefying bacteria. Nature, London 128, 1041-1042.

OWEN, R. J. \& LAPAGE, S. P. (1974). A comparison of strains of King's Group IIb of Flavobacterium with Flavobacterium meningosepticum. Antonie van Leeuwenhoek 40, 255-264.

Shewan, J. M., Hobis, G. \& Hodgkiss, W. (1960). A determinative scheme for the identification of certain genera of Gram-negative bacteria with special reference to the Pseudomonadaceae. Journal of Applied Bacteriology 23, 379-390.

SNEATH, P. H. A. (1957). The application of computers to taxonomy. Journal of General Microbiology 17, 201-226.

StANiER, R. Y. (1942). The Cytophaga group: a contribution to the biology of myxobacteria. Bacteriological Reviews 6, 143-196.

Thornley, M. J. (1960). The differentiation of Pseudomonas from other Gram-negative bacteria on the basis of arginine metabolism. Journal of Applied Bacteriology 23, 37-52.

TURVEY, J. R. \& Christison, J. (1967). The hydrolysis of algal galactans by enzymes from a Cytophaga species. Biochemical Journal 105, 311-316.

Vattuone, M. A., De Flores, E. A. \& Sampietro, A. R. (1975). Isolation of neoagarobiose and neoagarotetraose from agarose digested by Pseudomonas elongata. Carbohydrate Research 39, 164-167.

WISHART, D. (1969). Fortran II programs for 8 methods of cluster analysis. Computer Contribution 38, State Geological Survey, University of Kansas, Lawrence, U.S.A.

YAPHE, W. (1966). The purification and properties of an agarase from a marine bacterium, Pseudomonas atlantica. Proceedings of the 5th International Seaweed Symposium, pp. 333-335. Oxford: Pergamon Press. 